\title{
Metacognitive awareness of skilled and less-skilled EFL writers
}

\author{
Majid Farahian *iD and Farnaz Avarzamani
}

\author{
* Correspondence: farahian@iauksh. \\ ac.ir \\ Department of ELT, College of \\ Literature and Humanities, \\ Kermanshah Branch, Islamic Azad \\ University, Kermanshah, Iran
}

\begin{abstract}
The present study sought the differences between more and less proficient EFL (English as a Foreign Language) writers regarding their metacognitive awareness of writing (MAW). We also examined the relationship between MAW and EFL writing success. We used a validated MAW questionnaire for a comprehensive evaluation of the writers' metacognitive awareness. The results demonstrated that skillful EFL writers benefit from higher metacognitive awareness. Furthermore, we found that metacognitive awareness (and its sub-categories) is positively correlated with writing proficiency, except for avoidance strategy which showed a negative correlation. The mixed design of this study which is a part of a larger project would help researchers to gain new insights into the role of metacognitive awareness in EFL writing success.
\end{abstract}

Keywords: Metacognitive awareness, Metacognition, Metacognitive awareness of writing, EFL writing, Expert and novice writers

\section{Introduction}

Metacognition and its role in the process of writing have been given a credit by different lines of research studies, each having its own emphasis on the issue. Cognitive psychology, developmental psychology, and social cognitive psychology, each has had its own share of experimental research on metacognition and have contributed to theoretical developments.

In general terms, metacognition is thinking about our thinking and was defined as "the knowledge and regulation about cognitive phenomena" (Yu-Ling and Shih-Guey 2001, p. 1). The vital role of metacognition in the writing process has been widely acknowledged after the emergence of process-oriented approaches in writing. As a notable instance, Hayes and Flower (1980) who focused mainly on the critical role of metacognition argued that "a great part of the skill in writing is the ability to monitor and direct one's own composing process" (p. 39). Besides, Hacker, Keener, and Kircher (2009) have the same approach and maintain that "not only are metacognitive monitoring and control essential components of writing, but that writing is applied metacognition" (p. 154). In this regard, one may seek to understand the nature of the relationship between metacognition and writing. Magno (2008), who investigated the cognitive and affective predictors of English writing proficiency such as metacognition and anxiety among EFL learners found that among other factors, metacognition was highly related to writing proficiency.

(c) The Author(s). 2018 Open Access This article is distributed under the terms of the Creative Commons Attribution 4.0 International License (http://creativecommons.org/licenses/by/4.0/), which permits unrestricted use, distribution, and reproduction in any medium, provided you give appropriate credit to the original author(s) and the source, provide a link to the Creative Commons license, and indicate if changes were made. 
Interestingly, metacognition has also been regarded as a construct which could discriminate efficient and poor writers and it may develop as the writers grow older and go to higher levels in school. According to what Harris, Santangelo, and Graham (2010) obtained, substantial research has come to the conclusions that (1) efficient writers possess more knowledge of writing than less effective writers; (2) age and schooling run parallel with writing ability; (3) a writer's knowledge of writing is related to his performance in writing; and (4) if instruction in writing is combined with meaningful practice, the output and quality improves. They also revealed that efficient writers have more knowledge of the elements of composition and are more aware of the characteristics of high-quality compositions than poor writers. Accordingly, they are familiar with the higher order processes, such as revising and writing strategies. Unlike efficient writers, the knowledge of the less effective writers regarding writing processes is limited to form, but not the function of the composition. Therefore, they are expected, for example, to know more about writing mechanics than writing strategies. Having compared more skilled with less skilled writers, Abdullah, Bakar, Ali, and Yaacob (2011) demonstrated that both good and weak SL (second language) writers shared similar cognitive strategies, however, they were different in terms of the reasons and the ways they used strategies while writing.

As can be inferred, many scholars have touched on the important role of the metacognitive awareness in FL (Foreign Language)/SL writing in general, meanwhile, far fewer studies (e.g. Ruan 2014; Victori 1999) have investigated the significance of different types of metacognitive awareness (categories and sub-categories), especially in the domain of FL writing achievement. With regards to the categories of metacognitive awareness, Yu-Ling and Shih-Guey (2001) defined declarative knowledge as "knowing "what" are the things"; procedural knowledge as "knowing "how" to do things"; and conditional knowledge as "knowing "why" and "when" the strategies or procedures are appropriate" (p. 3). Finally, Regulation of Cognition was defined by Schraw and Moshman (1995) as "metacognitive activities that help control one's thinking or learning" (p. 354). In the present study, we considered both categories and sub-categories of MAW using a well-developed and validated self-design questionnaire (Farahian, 2017).

To our knowledge, no earlier study of FL/SL writing has used a measure that could cover metacognitive awareness with its developed categories along with their sub-categories. Although Yanyan (2010) developed a metacognitive knowledge questionnaire, it only explored learners' metacognitive knowledge and thus metacognitive experience or regulation of competence was not elicited by the questionnaire. The other limitation of the study was that there was no report of the validation procedure of the questionnaire. In order for bridging the existing gap, an inclusive and validated questionnaire was developed by Farahian (2017). We used the questionnaire in the present study so as to conduct quantitative analyses as a complementation for the earlier study by Maftoon, Birjandi, and Farahian (2014).

Finally, our main objectives were to see whether skilled and less-skilled EFL writers are different in terms of their writing MAW in general and to investigate the relationships between MAW and its categories and sub-categories with EFL writing proficiency. In this regard, we preferred to run correlational analyses instead of causal comparatives since we were determined to find out how related are the variables. In 
fact, many studies have used comparative analyses instead of predictive ones. Therefore, it seemed to us that correlational analysis is a more natural approach for investigating the role each sub-category of the MAW could play. In the following section, the related literature is reviewed to present essential information on what has been done so far regarding the role of metacognition in FL writing.

\section{Research Questions (RQ)}

According to the objectives of the present study, these questions were formulated:

(1) Do skilled and less-skilled EFL writers take advantage of metacognitive awareness differently?

(2) Is there any significant relationship between metacognitive awareness and English writing proficiency of EFL learners?

(3) Is/are there any significant relationship(s) between sub-categories of metacognitive awareness and English writing proficiency of EFL learners?

\section{Literature review}

Since cognitive and developmental psychology have much in common in terms of the role of metacognition in learning (Koriat 2002), a brief review of studies in EFL context which has been mostly influenced by cognitive psychology and developmental psychology will be briefly reviewed here. It should be noted that social cognitive psychology regards metacognition as one of the components of self-regulation and tends to investigate self-regulation as the attribute that controls the writing process (Dinsmore et al. 2008). Therefore, studies which explore the role of self-regulation in writing adopt a much broader view and hence are not mentioned here.

Metacognitive knowledge plays a great role, similar but not exactly identical to the first language, in cognitive activities which are responsible for language learning (Flavell 1979). Regarding writing, in particular, it is argued that employing metacognitive strategies has significant effects not only on the global levels, but also on the content, organization, vocabulary, and mechanics of writing (Dülger 2011). Moreover, research findings have revealed that successful learners employ this knowledge effectively to learn the target language (Wenden 1998).

In a study which investigated the relationship between metacognitive abilities and writing performance in the first as well as the foreign language, Devine, Railey, and Boshoff (1993) found a potential link between metacognitive knowledge and learners' writing. As the study suggests, cognitive models have important contributions to the writing task performance in both L1 (first language) and L2 (second language). In addition, based on the findings, metacognition plays a more important role than linguistic knowledge in effective L2 writing. The authors also report that ineffective SL writers lack sufficient metacognitive knowledge. Above all, less skilled L2 writers do not set goals for the writing tasks. In the same vein, Saddler and Graham (2007) noted that skilled writers are more purposeful in their writing and are more aware of the writing benefits. Another study that considered both L1 and L2 was Schoonen et al. (2003) in which they reported that metacognitive and linguistic knowledge was highly correlated with the learners' writing proficiency. 
Furthermore, metacognitive knowledge showed a higher variance than other variables in both FL and first language. It was also found that writing in L2 was more demanding than writing in L1 since, as the authors explain, "several of these constituent abilities may be less developed than one's first language" (p. 166).

In an attempt to assess the relationship between metacognitive personal knowledge, task knowledge, and strategy knowledge and the writing performance of ESL (English as a Second Language) students, Kasper (1997) explored the metacognitive growth of intermediate and advanced level ESL learners on their writing performance. The findings revealed that the SL learners who received higher scores on their writing tasks were those who had gained higher ratings on all three metacognitive variables, namely, person knowledge, task knowledge and strategy knowledge. Thus, as Kasper (1997) concludes, there is a positive correlation between metacognitive knowledge and writing performance of the ESL learners.

In a case study, Victori (1999) reported that the ineffective writers ineptly employed their metacognitive knowledge, and they also made limited use of it. Such a scant and limited use of metacognition affected the learners' use of strategies. Even, as Victori (1999) maintains, "this knowledge determines the type of strategy or writing approach to be adopted by the writer" (p. 549). On the contrary, the effective writers used the person, task, and strategy knowledge more appropriately; consequently, this "endowed them with a sound basis, with which to make informed decisions and, thus, with better tools for approaching their writing" (Victori 1999, p. 550). In the same vein, Baker (2010) reported a clear distinction between less and more skilled writers regarding both metacognitive knowledge and control. To clarify the difference, Baker (2010) concludes that better writers focus more on the function of writing, whereas poor writers focus more on the form. When asked about their conceptions of writing, better writers discuss the qualities of good writing, such as having a clear beginning, middle, and end, whereas poor writers discuss spelling all of the words correctly. Skilled writers have a higher-order awareness of the writing process, such as awareness of the organization, whereas less skilled writers tend to focus on lower-order processes, dealing with spelling, grammar, and pronunciation.

Angelova (2001) also observed a direct link between the learners' writing performance and metacognitive knowledge and found that there was a link between EFL learners' metacognitive knowledge and quality of writing. The results from these studies clearly indicated that the reason for the EFL writers' failure in writing is that they did not possess the conscious cognitive knowledge of the writing process. It was also revealed that the metacognitive strategies employed by the poor writers differed from those of skilled writers in that the poor writers began writing with no specific plan and aimed to write as much as possible. Finally, Razı (2014) highlighted "successful language learners are aware of which strategies they use and they select the most suitable ones for themselves. They can also explain why they use certain kind of strategies" (p. 11).

Based on the study carried out by Maftoon et al. (2014) concerning the knowledge of cognition and regulation of cognition as the broad categories of the MAW, a framework was created during the qualitative analysis on the participants' metacognitive awareness. The summary of the obtained results is summarized in Table 1. 
Table 1 Skilled vs. less-skilled EFL writing in terms of metacognitive awareness

\begin{tabular}{|c|c|}
\hline \\
\hline \multicolumn{2}{|l|}{$\frac{\text { Knowledge of Cognition }}{\text { Skilled EFL writers }}$} \\
\hline 1. Have higher self-concept and self-efficacy & 1. Have lower Self-concept and self-efficacy \\
\hline 2. Have negative attitude towards mental translation & $\begin{array}{l}\text { 2. Have negative attitude towards mental } \\
\text { translation }\end{array}$ \\
\hline $\begin{array}{l}\text { 3. Value FL reading both for gaining linguistic } \\
\text { (particularly vocabulary), and world knowledge }\end{array}$ & $\begin{array}{l}\text { 3. Value FL reading mostly for gaining linguistic } \\
\text { knowledge (particularly vocabulary) }\end{array}$ \\
\hline 4. Relatively aware of the text organization & 4. Little or no awareness of the text organization \\
\hline 5. Aware of text-type & 5. Unaware of text-type \\
\hline 6. Do not emphasize linguistic resources & 6. Overemphasize the role of vocabulary \\
\hline 7. Less likely to rely on topic familiarity & 7. More likely to rely on topic familiarity \\
\hline $\begin{array}{l}\text { 8. Have higher degrees of awareness of why and when of } \\
\text { their applied strategies }\end{array}$ & $\begin{array}{l}\text { 8. Have lower degrees of awareness of why and } \\
\text { when of their applied strategies }\end{array}$ \\
\hline $\begin{array}{l}\text { 9. Aware of planning and drafting strategies but do } \\
\text { not employ them constantly (slightly better). }\end{array}$ & $\begin{array}{l}\text { 9. Aware of planning and drafting strategies but } \\
\text { do not employ them constantly. }\end{array}$ \\
\hline $\begin{array}{l}\text { 10. Prefer English as a medium for planning and } \\
\text { have their global and original plan }\end{array}$ & $\begin{array}{l}\text { 10. Do not use English as a medium for } \\
\text { planning and are unsure about their writing }\end{array}$ \\
\hline 11. More likely to take the audience into consideration & $\begin{array}{l}\text { 11. Less likely to take the audience into } \\
\text { consideration }\end{array}$ \\
\hline 12. Use linguistic, as well as content and layout monitoring & 12. Overuse the linguistic monitoring \\
\hline 13. More aware of the importance of time management & $\begin{array}{l}\text { 13. Less aware of the importance of time } \\
\text { management }\end{array}$ \\
\hline 14. Less likely to avoid difficult structures and vocabularies & $\begin{array}{l}\text { 14. More likely to avoid difficult structures and } \\
\text { vocabularies }\end{array}$ \\
\hline $\begin{array}{l}\text { 15. Pay attention to both lower and higher-order processes } \\
\text { of writing }\end{array}$ & $\begin{array}{l}\text { 15. Pay more attention to lower-order processes } \\
\text { of writing }\end{array}$ \\
\hline 16. Less likely to seek help and guidance & $\begin{array}{l}\text { 16. More likely to seek help and } \\
\text { guidance }\end{array}$ \\
\hline $\begin{array}{l}\text { 17. Rely on their mother tongue to generate ideas and } \\
\text { revise the text }\end{array}$ & $\begin{array}{l}\text { 17. Rely on their mother tongue to prepare the } \\
\text { first draft }\end{array}$ \\
\hline $\begin{array}{l}\text { 18. Concentrate on writing dimensions like communicative } \\
\text { purpose, content, and goal to evaluate their writing }\end{array}$ & $\begin{array}{l}\text { 18. Concentrate on the surface structure to } \\
\text { evaluate their writing }\end{array}$ \\
\hline $\begin{array}{l}\text { 19. Revise surface content features, and the text } \\
\text { organization }\end{array}$ & 19. Revise surface level features \\
\hline
\end{tabular}

\section{Method}

Research design

The whole project regarding the investigation of the metacognitive awareness of skilled and less-skilled EFL writers adopted a mixed (both qualitative and quantitative) approaches. The present study reports the results obtained from the quantitative analyses of the participants' responses to the MAWQ (Metacognitive Awareness of Writing Questionnaire).

\section{Participants}

Out of 538 participants, 59 students voluntarily take part in the interview. After scoring the essays and applying Jacobs et al. (1981) we noticed that the number of less skilled writers was considerably higher than the skilled writers (16 skilled and 43 less-skilled EFL writers); Besides, the group variances were not homogeneous. Therefore, groups could not be subjected to accurate statistical analysis (Zimmerman 1987) As such, we randomly 
dropped some participants from the skilled writers' group to have equal number in both groups. Accordingly, there was an equal number of 16 in each group.

They were selected from a population $(n=538)$ who were Iranian EFL university students majoring in English teaching, translation, and literature. Table 2 summarizes the English proficiency of the population based on their paper-based TOEFL (Test of English as a Foreign Language) exam results.

\section{Instrumentation}

The MAWQ was constructed and developed based on the view that writing metacognitive awareness, with two recognized broad categories (i.e. Knowledge of Cognition \& Regulation of cognition) contains subcomponents which play critical roles in determining individuals' metacognitive awareness in terms of EFL writing. In the qualitative analyses of writers' essays (Maftoon et al. 2014), a framework emerged that contributed to a wider understanding of the role of metacognition in foreign language writing, on one hand, and the development of an inclusive survey, on the other hand (See the final version of the MAWQ in Appendix). In the questionnaire which contains 36 items, the first 20 items are classified under the first broad category of Knowledge of Cognition within which 13 items assess declarative knowledge awareness (Person $=3$, General Facts $=5$, Task Knowledge $=5$ ), 3 items are related to procedural knowledge, 4 items measure conditional knowledge. In the second broad category of Regulation of Cognition, 5 items are for the assessment of Planning \& Drafting, 4 items for General Strategies, 2 items for Allocating time and place, 2 items for Avoidance, and finally, 3 items for Revision.

The knowledge of cognition and its components enjoyed acceptable reliability. The reliability indices ranged from .67 to .91 . To examine the validity of the scale exploratory and confirmatory factor Analyses method was used to ensure the relationships among variables (see, Farahian (2017).

\section{Procedures}

The following steps were taken in order to develop the MAWQ. First, a language proficiency test (TOEFL-paper based) was given to 538 available EFL participants. Based on the results gained from the proficiency test, the participants were divided across three proficiency levels (see Table 2). Next, 59 EFL learners from the intermediate and advanced groups agreed to take part in a timed-essay test and the interview sessions. Based on their essay scores, the participants were divided into skilled and less-skilled EFL writers using Jacobs et al. (1981) composition profile. The essays were rated by three TEFL university instructors using the Jacobs et al. (1981) scale which measures the written ability of the learners from the perspectives of content, organization, vocabulary, and language use. Based on Jacobs et al. (1981) those who scored 68 and above were regarded as skilled

Table 2 The percentage of proficiency level of the participants

\begin{tabular}{lll}
\hline Group & Number & Percentage \\
\hline Advanced & 70 & $13 \%$ \\
Intermediate & 366 & $68 \%$ \\
Elementary & 102 & $18.96 \%$ \\
\hline
\end{tabular}


writers. Accordingly, 59 participants were divided into 43 skilled and 16 less-skilled writers. It should be mentioned that the consistency of the raters was calculated by $\alpha$-Cronbach index showing a high reliability among all raters (0.74).

Subsequently, the interview which was prepared according to the Dörnyei's guidelines (2003) was conducted. The interview questions and the final obtained findings can be found in Maftoon et al. (2014). After the content analysis of responses, the preliminary items were prepared. Five experts passed their judgments on the statements. The resultant questionnaire was piloted with twenty participants. They were required to identify any unclear or ambiguous item and to write their comments regarding the items. The main version of the questionnaire was prepared and distributed among the participants.

Eventually, we conducted the quantitative analyses as a follow-up study to the qualitative investigation to explore the correlation between EFL learners' writing proficiency and their metacognitive awareness (together with its sub-categories), as well as finding the differences between metacognitive awareness of skilled and less skilled EFL writers.

It should be noted that although the terms "efficient" and "poor" writers have extensively been extensively used in the related literature, "successful" versus "unsuccessful", and "skilled" versus "less-skilled" are more accurate labels which differentiate proficient from less proficient writers. That is why for the consistency of the terms, skilled and less skilled labels are used in the present study.

\section{Data analysis}

To answer the first research question, we conducted the independent samples t-test, and to investigate the second and third questions, we employed the Pearson Correlation analysis. For the purpose of assessing the normality of our data, we conducted Shapiro-Wilk to make sure that the normality assumption is met. It is also noteworthy that we corrected the unequal sample sizes by random case selection of the larger group (Skilled writers). Accordingly, the groups were compared with 16 members in each. All the statistical analyses were undertaken in the SPSS 22 software.

\section{Results}

The table below describes the two groups of writers statistically from the vantage point of their general metacognitive awareness in FL writing. Table 4 reports the normality of data in the groups.

Base on Table 3, the mean for MAW is much greater in the group of skilled writers. The inferential statistics (Table 5) will show if the difference is statistically significant. Besides, the values in the Standard Deviation (SD) column show that the MAW scores of less-skilled writers were almost twice as varied as the ones in the skilled group. As a complement to the SD, we reported the Standard Error (SE) as well.

Table 3 Descriptive statistics of MARQ by groups

\begin{tabular}{lllll}
\hline EFL Writers & $\mathrm{N}$ & Mean & Std. Deviation (SD) & Std. Error (SE) \\
\hline Skilled writers & 16 & 137.50 & 9.76 & 2.44 \\
Less-skilled writers & 16 & 67.12 & 18.77 & 4.69 \\
\hline
\end{tabular}


Based on Shapiro-Wilk (S-W) which is the most powerful test for small samples (Razali and Wah 2011), a significance value greater than 0.05 indicates that the distribution of the sample does not significantly differ from a normal distribution. In contrast, significance values lower than 0.05 tell us otherwise (Ho, 2014). According to Table 4, both $p$-values reported are greater than 0.05 and thus both variables comply with the normality assumption.

Findings of the differences between skilled and less-skilled EFL writers regarding their metacognitive awareness of writing

To explore whether there is any significant difference between the groups regarding their metacognitive awareness of writing, an independent $t$-test was run. Since the variance homogeneity of the data was not met, we considered the result in the second row of the able (Equal variances not assumed).

As Table 5 displays, there is a significant difference between skilled and less-skilled writers in terms of their overall metacognitive awareness. In other words, the MAW is greater in skilled writers' group meaning that proficient EFL writers are metacognitively more aware than their less-skilled counterpart. Therefore, we conclude that skilled and less-skilled EFL writers take advantage of metacognitive awareness differently. The authors also calculated the effect size (Cohen) to find the magnitude of this distinction. The obtained result for effect size is 6.36 which is a large one in this regard indicating that the EFL writers' difference was largely accounted by their metacognitive awareness in writing.

The correlations between metacognitive awareness (and its sub-categories) and English writing proficiency

As was reported in the qualitative analyses, skilled and less-skilled EFL writers were different regarding the components and sub-components of writing metacognitive awareness which we identified in the framework (Maftoon et al. 2014). In the present study, we aimed to analyze the above-mentioned relationships quantitatively so as to find whether there exist significant relationships and if there are some, which of them are stronger than others in the categories of MAW. To that end, the correlations between MAW (both overall and its components) and writing proficiency were calculated to answer the second and third research questions. We employed the Product Moment Coefficient the results of which are shown in Table 6.

As was demonstrated by Maftoon et al. (2014), successful and less successful EFL writers were different in most of the metacognitive awareness sub-categories. Our statistical analyses also confirmed such a considerable difference in general. As a further clarification, we decided to investigate the relationship between writing proficiency and metacognitive awareness on one hand (to answer the second $\mathrm{RQ}$ ), and the relationship between writing proficiency and the categories (and sub-categories) of FL writing metacognitive awareness (to answer the third RQ), on the other hand.

Table 4 Test of sample normality

\begin{tabular}{llll}
\hline Shapiro-Wilk & & & \\
\hline MAW & df & Statistic & Sig. \\
\hline Skilled & 16 & .963 & .716 \\
Less Skilled & 16 & .929 & .233 \\
\hline
\end{tabular}


Table $\mathbf{5}$ Independent samples test between the MAWQ and writing proficiency

\begin{tabular}{|c|c|c|c|c|c|c|c|}
\hline & \multicolumn{2}{|c|}{ Levene'sTest } & \multicolumn{5}{|l|}{ t-test } \\
\hline & F & Sig & $\mathrm{t}$ & $d f$ & $\begin{array}{l}\text { Sig. } \\
\text { (2-tailed) }\end{array}$ & $\begin{array}{l}\text { Mean } \\
\text { Difference }\end{array}$ & $\begin{array}{l}\text { Std. Error } \\
\text { Difference }\end{array}$ \\
\hline Equal variances assumed & 4.59 & .040 & 14.49 & 30 & .000 & 81.93 & 5.65 \\
\hline Equal variances not assumed ${ }^{a}$ & & & 14.49 & 23.24 & $.000^{*}$ & 81.93 & 5.65 \\
\hline
\end{tabular}

As can be seen in Table 5, MAW has a strong positive relationship with writing proficiency of our participants. The identified categories of MAW also show significant 'positive' (except for avoidance) correlations with writing skill and among them, the strongest relationship belongs to Writing Proficiency and Regulation of Cognition (General Strategies) with the Pearson correlation of .87. On the other hand, the Pearson correlation of Writing Proficiency and Declarative Knowledge (General Facts) were less than others in the table (.70), though it is still highly significant. All in all, it can be concluded that as EFL learners' metacognitive awareness of writing increases as their level of proficiency of writing grows.

\section{Discussion}

The findings showed a significant difference in the performance of both groups, and it was revealed that skilled writers performed better at MAWRQ, suggesting there may be a link between EFL learners' quality of writing and metacognitive knowledge. Accordingly, we were encouraged to conduct correlational analyses in order to look more closely into the possible links between FL writing proficiency and noteworthy MAW sub-categories which have already been identified in the framework presented by Maftoon et al. (2014).

The findings of the present study shed some light on the first research question as a comparative question and the second and third as correlational ones. First, we found that the two groups are considerably different in that the skilled writers outweighed the less-skilled in terms of the general MAW score. This is in harmony with many earlier studies (Baker 2010; Harris et al. 2010; Kasper 1997; Schoonen et al. 2003; Victori 1999).

Table 6 Correlations between MAW (and its sub-categories) and writing proficiency

\begin{tabular}{lll}
\hline Variables & $\begin{array}{c}\text { Pearson } \\
\text { Correlation }\end{array}$ & Sig. \\
\hline Writing Proficiency (WP) \& MAW & & \\
WP and MAW & .83 & .00 \\
WP \& MAW Sub-categories & & \\
WP \& Declarative Knowledge (Person) & .73 & .00 \\
WP \& Declarative Knowledge (General Facts) & .70 & .00 \\
WP \& Declarative Knowledge (Task Knowledge) & .78 & .00 \\
WP \& Procedural Knowledge & .84 & .00 \\
WP \& Conditional Knowledge & .74 & .00 \\
WP \& Regulation of Cognition (Planning \& Drafting) & .76 & .00 \\
WP \& Regulation of Cognition (General Strategies) & .87 & .00 \\
WP \& Regulation of Cognition (General on-line strategies- Time \& Place Allocation) & .78 & .00 \\
WP \& Regulation of Cognition (General on-line strategies- Avoidance) & -.78 & .00 \\
WP \& Regulation of Cognition (General on-line strategies- Revision) & .72 & .00 \\
\hline
\end{tabular}


The results obtained from the qualitative study of our sample (see Maftoon et al. 2014) also suggest that successful writers showed a far more awareness of the process of writing. They were more aware of their strength and weaknesses as well. In contrast, while less-successful writers reported having awareness of knowledge of metacognition, neither were they able to employ them in writing nor did they know how to make use of them since, as speculated in the literature (Hamp-Lyons 1993), they largely focused on lower-order processes which mostly deal with spelling, grammar, and vocabulary. This, as Victori (1999) suggests, indicates that the metacognitive awareness of many ESL writers is limited and inadequate.

Congruent with previous studies (Tsai 2009; Victori 1999), the analysis of the semi-structured interviews in Maftoon et al. (2014) indicated that skilled and novice EFL writers have also differences in the type of their metacognitive awareness (whether declarative or regulatory) and/or the degree of the employment of their knowledge. The present study also acknowledged these differences and links.

Because of the key role of metacognition in FL writing, it has been suggested that there is a potential link between these two (Angelova 2001; Kasper 1997). However, the relationship between metacognitive knowledge and FL writing performance has received less attention (Xiao 2007), specifically regarding its constituents. The present results seem to be inconsistent with the previous findings (Devine et al. 1993; Kasper 1997) concerning the relationship between metacognition and writing since the findings demonstrated that metacognitive awareness positively correlated with the participants' English writing performance. This means that students who rated successfully on MARQ were among the students who were labeled as skilled writers. The findings came as no surprise because all writing theories discuss the crucial role of self-regulatory and decision-making processes which can improve writing performance (Zimmerman and Bandura 1994). Further, Devine (1993) argues that the role of metacognition in writing is more crucial than the role of linguistic competence.

Besides the prominent role of general metacognitive ability, our quantitative analysis indicated that declarative metacognitive knowledge is positively correlated with FL writing proficiency and it was supported by many studies that we are going to remark while explaining each sub-category (person, translation, reading, and task knowledge) in the following paragraphs.

As to the awareness of knowledge of cognition in writing, while the obtained results indicated that there is a considerable positive relationship between knowledge of cognition and writing proficiency, semi-structured interviews (Maftoon et al. 2014), showed that proficient writers have positive attitude toward themselves and their abilities and also a greater motivation to write. This is in agreement with previous studies which documented that in foreign language context, writing has a positive relationship with attitude and self-esteem (Brooks 1985; Fahim and Khojaste Rad 2012; Hassan 1999; Khaldieh 2000; Prat-Sala and Redford 2012; Rose 1980; Victori 1999). It also mirrors the literature which indicates negative attitude and anxiety act as a hindrance to L2 writing (Ruan 2014). However, we should be cautious about the interpretation of these results because task type can also be an influential variable concerning self-concept and self-efficacy (Maftoon et al. 2014).

In addition to the impact of one's self-concept, the influences of mental translation and L2 reading (termed as general facts in Table 6) on L2 witting proficiency were also our concern. In a study by Cohen and Brooks-Carson (2001), the role of mental translation was investigated and it turned out that direct writing (in L2) is far more effective 
for writers, specifically, when there is some time pressure. The semi-structured interview in the qualitative study also showed that both skilled and less-skilled writers maintain that translation is a barrier to L2 writing. However, it was revealed that mental translation was unavoidable or even beneficial in the writing processes which is in line with what de Larios, Murphy, and Marin (2002) found. For example, some skillful writers (in the semi-structured interview) stated that they use their mother tongue for planning. However, the results are in controversy regarding the pros and cons of using the first language in the L2 writing processes (Sasaki 2002).

Together with the above-mentioned sub-categories of declarative knowledge, task awareness also plays its role in writing essays. We found that skilled writers are more familiar with text-type and its organization and thus showed more awareness of writing tasks. In this regard, Negretti (2012), explained that "mental representation of the task will, therefore, influence metacognitive dynamics entailed in writing" (p. 146). In fact, familiarity with writing as a task in general and text organization and text-type, in particular, seem to have a link with writing expertise. However, this type of declarative knowledge should be studied cautiously since the relationship seems to be reciprocal. In other words, task properties and conditions may affect writers' metacognitive awareness and their performance as well (Ong 2014).

With regard to the procedural knowledge and FL writing proficiency, we found that skilled writers were significantly more aware of the way they did the writing task. This was also revealed in their interviews (Maftoon et al. 2014), which is in line with what many scholars have remarked (e.g., de Larios et al. 2002; Razı 2014; Schraw and Moshman 1995; Yu-Ling \& Shih-Guey 2001) in that knowing how to write and being aware of the procedures one uses have to do with their L2 writing success. On the other hand, a substantive number of less-skilled writers not only showed a shallow understanding of declarative knowledge but they also lacked enough procedural knowledge to help them employ writing strategies. It should be mentioned that the skilled writers' responses regarding the procedural knowledge were varied in their interviews. Interestingly, some of the skilled writers were not able to articulate why and under what conditions they used writing strategies. Although such a gap has been referred to in the related literature (de Larios et al. 2002), there is a dearth of research studies on the issue.

Here there is a caveat that is our concern. Although skilled writers showed much higher procedural awareness, one cannot deny the fact that strategy has a capability of becoming implicit and automatized to that extent that it could be hardly ever accessible to skillful writers' consciousness (DeKeyser 2003; Scheffler and Cinciała 2010). Moreover, no agreements have been reached in term of the degree of consciousness involved in metacognitive knowledge and strategy (Cary and Reder 2002). Therefore, regarding the procedural awareness, relying on qualitative analyses rather quantitative ones would yield more reliable results. This issue also applies to conditional metacognitive awareness because some of the participants including skilled and less-skilled writers did not explicitly know why and when they do what they do while preparing an essay. However, skilled writers showed a higher awareness of the conditions in which they employ strategies and this was unveiled through giving explicit examples in their interviews.

Additionally, the findings indicated that regulation of cognition and its components have a positive correlation (except avoidance with negative correlation) with L2 writing scores. It means that writers with higher skills enjoy higher ability to regulate and manage their 
thoughts and actions when dealing with writing tasks. In line with the literature (Baker 2010), which postulates that regulatory process is handled differently among efficient and poor writers, noticeable differences were found between the groups regarding their awareness of regulation of cognition. In our study, regulatory skills include Planning $\mathcal{E}$ drafting, and general strategies. We also found other skills that are not directly classified under the regulation of cognition category but can affect it as online strategies. They are time and place allocation, avoidance, and revision (Maftoon et al. 2014).

Firstly, planning has always been regarded as a fundamental skill of skilled writers. Similar to the obtained results, scholars have found that skilled writers take more time to make organized plans before writing (Becker 2006; Manchón and de Larios 2007; Sasaki 2002; Victori 1999). In this regard, some studies showed that writers would not necessarily stick to their plan. In fact, their plan may be altered in the process of writing (Victori 1999; Sasaki 2002). On the other hand, in the qualitative phase of the study, it was found that writers (especially skilled ones) tended to follow their initial plans without changing (Maftoon et al. 2014). All in all, what is commonly accepted is that skillful writers devote more time and attention than less-skilled writers for planning.

Regarding time allocation as an online strategy, the present study showed that it has a significant positive relationship with higher writing achievement (L2 essay writing). This was supported by Zimmerman and Risemberg (1997) who referred to time management as an essential element of effective writing. The second online strategy was avoidance by which less-skilled writers escaped the expressions and structures that they did not know or had difficulty to use them. This strategy was the only one with negative correlation (See Table 6). In this regard, Victori (1999), remarked that laziness or lack of commitment may result in avoidance. In the same vein, Fahim and Noormohammadi (2014), reported that high achievers tend to take risks but low achievers are "(...meticulous about language learning, dislike ambiguity, and safeguard themselves by avoiding tentative steps)" (p. 1433).

Finally, regarding revision, we found that although revising at the level of structure is helpful, it is also needed to yield a refined text at the level of content. This is what the skillful writers reported they often engaged in. This is in agreement with what Yu-Ling and Shih-Guey (2001), and Victori (1999) found. This is also in tandem with Barkaoui (2007) who explains that less- skilled SL writers do not distinguish between editing and revising. Skilled writers, on the contrary, regarded revision as a strategy which reshapes their works. For them, revision is, as Barkaoui (2007) puts it, "a recursive process that permeates the whole writing endeavor" (p. 89). That is why the majority of skilled writers in the qualitative study (Maftoon et al. 2014) reported that they evaluated texts globally and less-skilled writers, on the other hand, paid more attention to local corrections.

\section{Conclusion}

In the present study, we aimed to investigate the MAW of skilled and less-skilled Iranian EFL learners quantitatively. Accordingly, we used a self-designed questionnaire in order to analyze the writers' awareness in an objective way as well. This study showed that the obtained results from our quantitative analyses are in harmony with what has been gained in the qualitative analyses (i.e. Maftoon et al. 2014). Regarding the metacognitive awareness components, the research results were in harmony with most of the previous studies. However, conducting rigorous research especially regarding procedural and conditional 
knowledge is a big challenge due to the lack of suitable measures on one hand, and the complicated nature of human consciousness on the other hand. We believe that conducting both qualitative and quantitative or mixed methods would shed more light on the role of metacognition in L2 writing.

The pedagogical implication of the obtained results lies in a better understanding of what is called 'good writing' and also in the development of a measure for recognizing metacognitive awareness in L2 writing. Only after better understanding, we could help students with lower degrees of metacognitive awareness to write cohesive essays. As maintained by Yu-Ling and Shih-Guey (2001), "EFL instructors can, therefore, help our students to strengthen their metacognitive models and learn to write well in the target language." (p. 12).

Moreover, knowing that higher skill of efficient EFL writers is, to a significant extent, due to their superiority in metacognitive awareness of writing processes would encourage teachers to take students' metacognitive awareness of writing more seriously into consideration. Consequently, the findings would inform language instructors regarding qualitative and quantitative differences in learners' awareness of knowledge and regulation of cognition. This will help language teachers to "be supportive and encouraging to learners, and attend to their voices from different venues to monitor, evaluate and regulate the teaching strategies employed" (Tsai 2009, p. 13).

As regards the issues that imposed some restrictions on our study, we would first refer to the small sample size, plus the unequal sample sizes that made us correct it at the expense of having an even smaller sample (16 in each of the writing proficiency groups). In fact, this was due to the unavailability of participants and thus we acknowledge that the results are not generalizable. On top of that, self-report data gathering tools such as questionnaires and interviews have their own weaknesses especially when the participants are reluctant (Jacobs and Paris 1987). Furthermore, the limitation inherent in the interview as the data collection technique was that the researcher had to rely on the interviewees' reports of their metacognitive awareness while the statements produced by the participants may have been distorted by their memories and imperfect recall.

Furthermore, ceiling and floor effects which are related to the limitation regarding the scope of research tools in capturing the existing data may have affected the results. That being the case, longitudinal research designs would give scholars a comprehensive data on L2 writing success from the metacognition vantage point.

As mentioned before, a retrospective interview was employed in the study. That is to say, the participants took part in a retrospective activity in which the participants were asked to report on their metacognitive awareness after they finished writing. One of the major shortcomings of retrospective methods is that learners may forget the mental processes. Furthermore, memory distortions may disrupt the flow of information. It is also assumed that retrospective methods can assess individuals' declarative knowledge. This means that the procedural knowledge which is employed in the process of composing is not adequately assessed through interviews. Accordingly, the participants' may provide the researcher with invalid data. As such, future studies with thinking aloud protocols accompanying the interview would gain a clearer view of the participants' metacognitive awareness. Moreover, further research with the recruitment of EFL learners from diverse regions of the country is also essential to enhance the generalizability of the findings. 


\section{Appendix}

Table 7 MAWQ (Metacognitive Awareness Writing Questionnaire)

\begin{tabular}{|c|c|c|c|c|c|c|}
\hline & Items & $\begin{array}{l}\text { Strongly } \\
\text { agree }\end{array}$ & Agree & $\begin{array}{l}\text { No } \\
\text { idea }\end{array}$ & Disagree & $\begin{array}{l}\text { Strongly } \\
\text { disagree }\end{array}$ \\
\hline 1. & Writing in English makes me feel bad about myself. & () & () & () & 0 & 0 \\
\hline 2. & $\begin{array}{l}\text { I think writing in English is more difficult than reading, } \\
\text { speaking, or listening in English. }\end{array}$ & 0 & () & 0 & 0 & 0 \\
\hline 3. & I believe a successful writer is born not made. & () & () & 0 & 0 & 0 \\
\hline 4. & $\begin{array}{l}\text { Topic familiarity has a significant effect on one's writing } \\
\text { output. }\end{array}$ & () & () & ) & 0 & () \\
\hline 5. & $\begin{array}{l}\text { A skillful writer is familiar with writing strategies (e.g., planning } \\
\text { or revising the text). }\end{array}$ & () & ) & 0 & 0 & 0 \\
\hline 6. & At every stage of writing, a skillful writer avoids making error. & () & () & () & 0 & 0 \\
\hline 7. & $\begin{array}{l}\text { Dwelling on vocabulary items and grammar interferes with } \\
\text { getting the message across. }\end{array}$ & () & () & () & 0 & () \\
\hline 8. & $\begin{array}{l}\text { Word by word translation from first language to English } \\
\text { negatively affects one's ability in writing. }\end{array}$ & 0 & 0 & 0 & 0 & 0 \\
\hline 9. & $\begin{array}{l}\text { I am aware of different types of text types in writing } \\
\text { (e.g., expository, descriptive, narrative). }\end{array}$ & 0 & () & 0 & 0 & 0 \\
\hline 10. & $\begin{array}{l}\text { I know that the necessary components of an essay are } \\
\text { introduction, body, and conclusion. }\end{array}$ & 0 & () & 0 & 0 & () \\
\hline 11. & $\begin{array}{l}\text { I am familiar with cohesive ties (e.g., therefore, as a result, } \\
\text { firstly). }\end{array}$ & 0 & () & () & 0 & () \\
\hline 12. & I know what a coherent piece of writing is. & 0 & 0 & ) & 0 & 0 \\
\hline 13. & I am good at writing topic sentences. & 0 & 0 & 0 & 0 & 0 \\
\hline 14. & I know what to do at each stage of writing. & 0 & () & () & 0 & () \\
\hline 15. & I find myself applying writing strategies with little difficulty. & 0 & () & () & 0 & () \\
\hline 16. & $\begin{array}{l}\text { I know how to develop an appropriate introduction, body, } \\
\text { and conclusion for my essay. }\end{array}$ & 0 & () & 0 & 0 & 0 \\
\hline 17. & I know when to use a writing strategy. & () & () & () & 0 & () \\
\hline 18 & $\begin{array}{l}\text { I know which writing strategy best serves the purpose } \\
\text { I have in my mind. }\end{array}$ & 0 & () & () & 0 & 0 \\
\hline 19. & $\begin{array}{l}\text { I know what to do when the writing strategies I employ } \\
\text { are not effective. }\end{array}$ & 0 & () & () & 0 & 0 \\
\hline 20. & $\begin{array}{l}\text { I know which problem in writing needs much more } \\
\text { attention than others. }\end{array}$ & 0 & () & 0 & 0 & 0 \\
\hline 21. & Before I start to write, I prepare an outline. & () & () & () & 0 & () \\
\hline 22. & I have frequent false starts since I do not know how to begin. & 0 & () & () & 0 & () \\
\hline 23. & $\begin{array}{l}\text { Before I start to write, I find myself visualizing what I am } \\
\text { going to write. }\end{array}$ & 0 & () & () & 0 & 0 \\
\hline 24. & $\begin{array}{l}\text { My initial planning is restricted to the language resources (e.g., } \\
\text { vocabulary, grammar, expressions) I need to use in my essay. }\end{array}$ & () & () & () & 0 & () \\
\hline 25. & $\begin{array}{l}\text { I set goals and sub-goals before writing (e.g., to satisfy the } \\
\text { teacher, to be able to write emails, to be a professional writer). }\end{array}$ & ) & 0 & 0 & 0 & 0 \\
\hline 26. & $\begin{array}{l}\text { I find myself resorting to fixed sets of sentences I have in } \\
\text { mind instead of creating novel sentences. }\end{array}$ & ) & 0 & () & 0 & () \\
\hline 27. & $\begin{array}{l}\text { At every stage of writing, I use my background knowledge to } \\
\text { create the content. }\end{array}$ & () & 0 & () & 0 & () \\
\hline 28. & $\begin{array}{l}\text { I mainly focus on conveying the main message rather than } \\
\text { the details. }\end{array}$ & () & () & 0 & ) & 0 \\
\hline 29. & $\begin{array}{l}\text { I automatically concentrate on both the content and the } \\
\text { language of the text. }\end{array}$ & 0 & () & 0 & 0 & () \\
\hline 30. & I can effectively manage the time allocated to writing. & () & () & () & () & () \\
\hline
\end{tabular}


Table 7 MAWQ (Metacognitive Awareness Writing Questionnaire) (Continued)

\begin{tabular}{|c|c|c|c|c|c|c|}
\hline & Items & $\begin{array}{l}\text { Strongly } \\
\text { agree }\end{array}$ & Agree & $\begin{array}{l}\text { No } \\
\text { idea }\end{array}$ & Disagree & $\begin{array}{l}\text { Strongly } \\
\text { disagree }\end{array}$ \\
\hline 31. & I choose the right place and the right time in order to write. & () & () & () & 0 & () \\
\hline 32. & $\begin{array}{l}\text { I use avoidance strategies (e.g. when I do not know a certain } \\
\text { vocabulary item or structure, I avoid it). }\end{array}$ & 0 & () & () & () & () \\
\hline 33. & $\begin{array}{l}\text { When I cannot write complicated sentences, I develop other } \\
\text { simple ones. }\end{array}$ & () & () & 0 & 0 & 0 \\
\hline 34. & After I finish writing, I edit the content of my paper. & () & () & () & () & () \\
\hline 35. & $\begin{array}{l}\text { If I do revision, I do it at the textual features of the text (e.g., } \\
\text { vocabulary, grammar, spelling). }\end{array}$ & 0 & () & 0 & 0 & () \\
\hline 36. & If I do revision, I do it at both textual and the content levels. & () & () & 0 & 0 & 0 \\
\hline
\end{tabular}

Adapted from Farahian (2017)

\section{Abbreviations}

EFL: English as a Foreign Language; ESL: English as a Second Language; FL: Foreign language; L1: First language; L2: Second language; MAW: Metacognitive awareness of writing; MAWQ: Metacognitive Awareness of Writing Questionnaire; RQ: Research question(s); SL: Second language; TOEFL: Test of English as a Foreign Language; WP: Writing proficiency

\section{Availability of data and materials}

Please contact authors for data requests.

\section{Authors' contributions}

MF conducted the procedures, gathered the data, wrote the first draft and reviewed the final draft. FA performed the statistical analyses and wrote the final draft. Both authors read and approved the final manuscript.

\section{Authors' information}

Majid Farahian is an assistant professor in the Department of Foreign Languages in Islamic Azad University, Kermanshah Branch. He holds a Ph.D. in Applied Linguistics. His research interests include language education and foreign language writing. His published articles appear in both national and international journals. He also has worked as a reviewer for national and international journals.

Farnaz Avarzamani holds MA in TEFL and is an English teacher in Kermanshah, Iran. Her areas of interest include language education and psychology of language learning. She has published articles in international journals and blogs and has worked for international journals as a reviewer as well.

\section{Competing interests}

The authors declare that they have no competing interests.

\section{Publisher's Note}

Springer Nature remains neutral with regard to jurisdictional claims in published maps and institutional affiliations.

\section{Received: 15 December 2017 Accepted: 23 May 2018}

Published online: 05 June 2018

\section{References}

Abdullah, M. R. T. L., Bakar, Z. A., Ali, R. M., \& Yaacob, A. R. (2011). Writing strategies of Malaysian ESL undergraduate engineering learners. International Journal of Engineering \& Technology IJET-IJENS, 11(2), 1-9.

Angelova, M. (2001). Metacognitive knowledge in EFL writing. Academic Exchange Quarterly, 5(3), 78-83.

Baker, L. (2010). Metacognition. In V. G. Aukrust (Ed.), Learning and cognition in education (pp. 128-133). Oxford: Academy Press.

Barkaoui, K. (2007). Revision in second language writing: What teachers need to know. TESL Canada, 25(1), 81-92. https://doi.org/10.18806/tesl.v25i1.109.

Becker, A. (2006). A review of writing model research based on cognitive process. In A. Horning \& A. Becker (Eds.), Revision: History, theory, and practice (pp. 24-49). West Lafayette: Parlor Press.

Brooks, E. (1985). Case studies of the composing processes of five "unskilled" English-as-a-second language writers. New York: New York University. https://files.eric.ed.gov/fulltext/ED289340.pdf.

Cary, M.., \& Reder, L. M. (2002). Metacognition in strategy selection: Giving consciousness too much credit. In P. Chambres, M. Izaute, \& P. J. Marescaux (Eds.), Metacognition: Process, function, and use (pp. 63-78). New York: Kluwer.

Cohen, A. D., \& Brooks-Carson, A. (2001). Research on direct versus translated writing: Students' strategies and their results. The Modern Language Journal, 85(2), 169-188. https://doi.org/10.1111/0026-7902.00103.

de Larios, J. R., Murphy, L., \& Marin, J. (2002). A critical examination of L2 writing process research. In S. Ransdell \& M.-L. Barbier (Eds.), New directions for research in L2 writing (pp. 11-47). 
DeKeyser, R. (2003). Implicit and explicit learning. In C. Doughty \& M. H. Long (Eds.), The handbook of second language acquisition (pp. 313-348). Malden: Blackwell.

Devine, J. (1993). The role of metacognition in second language reading and writing. In J. G. Carson \& I. Leki (Eds.), Reading in the composition classroom: Second language perspectives (pp. 105-127). Boston: Heinle and Heinle.

Devine, J., Railey, K., \& Boshoff, P. (1993). The implications of cognitive models in L1 and L2 writing. Journal of Second Language Writing, 2(3), 203-225. https://doi.org/10.1016/1060-3743(93)90019-Y.

Dinsmore, D. L., Alexander, P. A., \& Loughlin, S. M. (2008). Focusing the conceptual lens on metacognition, self-regulation, and self-regulated learning. Educational Psychology Review, 20(4), 391-409. https://doi.org/10.1007/s10648-008-9083-6.

Dülger, O. (2011). Meta-cognitive strategies in developing EFL writing skills. Contemporary Online Language Education Journal, 1(2), 82-100.

Fahim, M., \& Khojaste Rad, S. (2012). The relationship between self-esteem and paragraph writing of Iranian EFL learners. Psychology, 3(1), 24-29. https://doi.org/10.4236/psych.2012.31004.

Fahim, M., \& Noormohammadi, R. (2014). The learner's side of foreign language learning: predicting language learning strategies from language learning styles among Iranian medical students. Journal of Language Teaching and Research, 5(6), 1424-1434. https://doi.org/10.4304/jttr.5.6.1424-1434.

Farahian, M. (2017). Developing and validating a metacognitive writing questionnaire for EFL learners. Issues in Educational Research, 27(4), 736-750.

Flavell, J. H. (1979). Metacognition and cognitive monitoring: A new area of cognitive-developmental inquiry. American Psychologist, 34(10), 906-911. https://doi.org/10.1037/0003-066X.34.10.906.

Hacker, D. J., Keener, M. C., \& Kircher, J. C. (2009). Writing is applied meta-cognition. In D. J. Hacker, J. Dunlosky, \& A. C. Graesser (Eds.), Handbook of metacognition in education (pp. 154-172). New York: Routledge.

Hamp-Lyons, L. (1993). Scoring procedures for ESL contexts. In L. Hamp-Lyons (Ed.), Assessing second language writing in academic contexts (pp. 241-276). Norwood: Ablex.

Harris, K. R., Santangelo, T., \& Graham, S. (2010). Metacognition and strategies instruction in writing. In H. S. Waters \& W. Schneider (Eds.), Metacognition, strategy use, and instruction (pp. 226-256). New York: London: The Guilford Press.

Hassan, B. A. (1999). The relationship of writing apprehension and self-esteem to the writing quality and quantity of EFL university students. Mansoura Faculty of Education Journal, 39, 1-36.

Hayes, J., \& Flower, L. (1980). Identifying the organization of writing processes. In L. Gregg \& E. Steinberg (Eds.), Cognitive processes in writing (pp. 3-30). Hillsdale, NJ: Lawrence Erlbaum.

Ho, R. (2014). Handbook of univariate and multivariate data analysis with IBM SPSS (2nd ed.). Boca Raton: CRC Press Book.

Jacobs, H. L., Zinkgraf, S. A., Wormuth, D. R., Hartifiel, V. G., \& Haughey, J. B. (1981). Testing ESL composition: A practical approach. Rowley: Newbury House Publishers.

Jacobs, J. E., \& Paris, S. G. (1987). Children's metacognition about reading: Issues in definition, measurement, and instruction. Educational Psychologist, 22, 225-278. https://doi.org/10.1080/00461520.1987.9653052.

Kasper, L. F. (1997). Assessing the metacognitive growth of ESL student writers. TESL- EJ, 3(1), 1-20.

Khaldieh, S. A. (2000). Learning strategies and writing processes of proficient vs. less-proficient1 learners of Arabic. Foreign Language Annals, 33(5), 522-533. https://doi.org/10.1111/j.1944-9720.2000.tb01996.x.

Koriat, A. (2002). Metacognition research: An interim report. In T. J. Perfect \& B. L. Schwartz (Eds.), Applied metacognition (pp. 261-286). Cambridge: Cambridge University Press.

Maftoon, P., Birjandi, P., \& Farahian, M. (2014). Investigating Iranian EFL learners' writing metacognitive awareness. International Journal of Research Studies in Education, 3(5), 37-51. https://doi.org/10.5861/ijrse.2014.896.

Magno, C. (2008). Reading strategy, amount of writing, metacognition, metamemory, and apprehension as predictors of English written proficiency. Asian EFL Journal, 29, 15-48.

Manchón, R. M., \& de Larios, J. R. (2007). On the temporal nature of planning in L1 and L2 composing. Language Learning, 57(4), 549-593. https://doi.org/10.1111/j.1467-9922.2007.00428.x.

Negretti, R. (2012). Metacognition in student academic writing: A longitudinal study of metacognitive awareness and its relation to task perception and evaluation of performance. Written Communication, 29(2), 142-179. https://doi.org/ $10.1177 / 0741088312438529$.

Ong, J. (2014). How do planning time and task conditions affect metacognitive processes of L2 writers? Journal of Second Language Writing, 23, 17-30. https://doi.org/10.1016/j.jslw.2013.10.002.

Prat-Sala, M., \& Redford, P. (2012). Writing essays: Does self-efficacy matter? The relationship between self-efficacy in reading and in writing and undergraduate students' performance in essay writing. Educational Psychology, 32(1), 9-20. https://doi.org/10.1080/01443410.2011.621411.

Razali, N. M., \& Wah, Y. B. (2011). Power comparisons of shapiro-wilk, kolmogorov-smirnov, lilliefors and Anderson-darling tests. Journal of statistical modeling and analytics, 2(1), 21-33.

Razı, Ö. (2014). An Investigation into the Metacognitive Writing Strategies of Turkish Cypriot University Students: Retrieved from http://web.aou.edu.lb/online-journals/issue-1.

Rose, M. (1980). Rigid rules, inflexible plans, and the stifling of language: A cognitivist analysis of writer's block. College Composition and Communication, 31(4), 389-401. https://doi.org/10.2307/356589.

Ruan, Z. (2014). Metacognitive awareness of EFL student writers in a Chinese ELT context. Language Awareness, 23(1-2), 76-90. https://doi.org/10.1080/09658416.2013.863901.

Saddler, B., \& Graham, S. (2007). The relationship between writing knowledge and writing performance among more and less skilled writers. Reading and Writing Quarterly, 23, 231-247.

Sasaki, M. (2002). Building an empirically-based model of EFL learners' writing processes. In S. Ransdell \& M. L. Barbier (Eds.), New directions for research in L2 writing (pp. 49-80). Dordrecht: Kluwer Academic.

Scheffler, P., \& Cinciała, M. (2010). Explicit grammar rules and L2 acquisition. ELT Journal, 65(1), 13-23. https:/doi.org/10.1093/elt/ccq019.

Schoonen, R., Gelderen, A. v., Glopper, K. d., Hulstijn, J., Simis, A., Snellings, P., \& Stevenson, M. (2003). First language and second language writing: The role of linguistic knowledge, speed of processing, and metacognitive knowledge. Language Learning, 53(1), 165-202. https://doi.org/10.1111/1467-9922.00213.

Schraw, G., \& Moshman, D. (1995). Metacognitive theories. Educational Psychology Review, 7(4), 351-371. https:// doi.org/10.1007/BF02212307. 
Tsai, H. M. (2009). Examining metacognitive performance between skilled and unskilled writers in an integrated EFL writing class. Proceedings of the 26th International Conference on English Teaching and Learning in the (pp. 678689). Republic of China.

Victori, M. (1999). An analysis of writing knowledge in EFL composing: A case study of two effective and two less effective writers. System, 27(4), 537-555. https://doi.org/10.1016/S0346-251X(99)00049-4.

Wenden, A. L. (1998). Metacognitive knowledge and language learning. Applied linguistics, 19(4), 515-537. https://doi. org/10.1093/applin/19.4.515.

Xiao, Y. (2007). Appling metacognition in EFL writing instruction in China. Reflections on English Teaching, 6, 19-33.

Yanyan, Z. (2010). Investigating the role of metacognitive knowledge in English writing. Papers in Applied Language Studies, 14, 25-46.

Yu-Ling, Y., \& Shih-Guey, J. (2001). Investigating the metacognitive awareness and strategies of English-majored university student writers. Retrieved from https://eric.ed.gov/?id=ED465281.

Zimmerman, B., \& Risemberg, R. (1997). Becoming a self-regulated writer: A social cognitive perspective. Contemporary Educational Psychology, 22, 73-101. https://doi.org/10.1006/ceps.1997.0919.

Zimmerman, B. J., \& Bandura, A. (1994). Impact of self-regulatory influences on writing course attainment. American Educational Research Journal, 31, 845-862. https://doi.org/10.3102/00028312031004845.

Zimmerman, D. W. (1987). Comparative power of student $t$ test and Mann-Whitney $U$ test for unequal sample sizes and variances. The Journal of Experimental Education, 55(3), 171-174.

Submit your manuscript to a SpringerOpen ${ }^{\circ}$ journal and benefit from:

- Convenient online submission

- Rigorous peer review

- Open access: articles freely available online

- High visibility within the field

- Retaining the copyright to your article

Submit your next manuscript at $\gg$ springeropen.com 